\title{
Sherman Alexie's Literary Works as Native American Social Realistic Projections
}

\author{
Md. Amir Hossain \\ Senior Lecturer (Full-Time), Department of English, \\ IBAIS University, Bangladesh \\ Research Associate (Part-Time), Uttara University, Bangladesh \\ S.M. Abu Nayem Sarker \\ Assistant Research Officer, Uttara University, Bangladesh
}

doi: 10.19044/esj.2016.v12n11p381 URL:http://dx.doi.org/10.19044/esj.2016.v12n11p381

\begin{abstract}
This paper aims to look at the social realistic issues in the context of Sherman Alexie's literary works. Alexie is one of the postmodern authors in the United States of America. He is very popular among his Native American society as well as community for representing social reality of his age. This paper is divided into several sections; each section shows a benchmark of the $21^{\text {st }}$ century Social Picture of the Native Americans in the light of Alexian Literary Works. It also scrutinizes stories, and novels with a view to highlighting a faithful picture of Native Americans in the light of everyday social issues, including poverty, alcoholism, unhealthiness, racism, and suicidal act. Basically, the main part of my paper deals with social problems of Native Americans in the United States of America as depicted in Alexie's literary works. It highlights an awareness of the Native Americans so as to keep themselves aloof from drug addiction, poverty, depression, and psychological trauma. Here I have also applied the critical theory of Social Realism with a view to unveiling a subtle literary affinity with Alexie's works. In this study, I would like to show the significance of this study, and research methodology as well.
\end{abstract}

Keywords: Alcoholism, Native Americans, Poverty, Racial Conflicts, Sherman Alexie, Social Realism, and Suicide

\section{Introduction}

Sherman Alexie (1966- ) is one of the most prominent Native American writers of the $21^{\text {st }}$ century. Alexie is well-known for his bold portrayal of the harsh social realities of reservation life. He has become a postmodern voice in the continuing search for Native American social reality 
and cultural identity. Alexie's works show dark humour, the debilitating influence of alcoholism, suicide, want of proper health care, unemployment, racial conflict, housing reservation, and poverty that pervade human life on the reservation as well as the anger that emerges from the distortion and annihilation of a true identity of Native American. He is recognized as an innovative realist and erudite contributor to the modern Native-American tradition. Alexie's work has been almost universally received as a revolutionary, bold, and realistically reflective writer. His poetry, short story, and fiction have been praised by critics, scholars and reviewers for the realistic portrayals of the Native-American experiences in resistance to the contemporary American mainstream. His talent, according to reviewers, lies in his ability to juxtapose humour with tragedy, historical figures with modern situations, and real people with fictitious characters. His works has received an equally laudatory feedback from the literary critics, Native Americans, and non-Native reading audience, and his writing having turned into the best sellers and award-winning books is clear evidence of the fact.

Alexian poetry, short stories and novels explore themes of despair, poverty, violence and alcoholism among the lives of Native American people. According to Sarah A. Quirk from the Dictionary of Library Biography, Alexie asks three questions across all of his literary works: "What does it mean to live as an Indian in this time? What does it mean to be an Indian man? Finally, what does it mean to live on an Indian reservation" (Quirk, 2003, pp.3-10)? Through these questions, Alexie would like to identify social reality on his age. The protagonists, in most of his literary works, exhibit a constant struggle with themselves and their own sense of powerlessness and hopelessness in the white American society. Alexie, through portraying his male and female characters, wants to show a critical aspect of social realism with a view to creating awareness of his own community and society.

For this purpose, this paper is designed to foster social realistic issues in contemporary Native American literature through dividing into several subsections. Each subsection is arranged to highlight the textual analysis of Alexie through applying the critical theory of social realism.

\section{Theoretical Framework}

Social Realism is a naturalistic realism focusing on social issues and the hardships of everyday life. The term refers to the urban American scene of the depressive artists, who were influenced by the Ashcan school of the early $20^{\text {th }}$ century New York. Social realism, an international art movement, refers to the work of painters, print-makers, photographers, and film-makers that draw attention to the everyday conditions of the working class and the poor; social realists are critical of the social structures which maintain these 
conditions. While the movement's characteristics vary from nation to nation, it almost always utilizes a form of descriptive, or critical realism. The principal source of the subject matter of the works of social realism is made up of problems connected with human life, the works, thoughts and actions of the people who are either trying to establish a hierarchic society or who are struggling for their rights in capitalist, rather than socialist countries.

Social Realistic literature does not depict people from the critical realist perspective. Critical realism puts oppressed and exploited people at the centre of its works, people for whom we must have pity, people who rebel only as individuals, those who are incapable of changing their lives and of building a new society. The literature of social realism portrays the people as great, organized force, the creative and moving force of history.

"Social Realism" is a literary term that derives from Russian inspired beliefs about the function of literature in a revolutionary socialist society. The international production of social realist fiction is characterized by a belief in the power of the word and in the writer's ability to portray in a satisfying documentary fashion the structure of social reality. Social realism is inspired in various ways by the Russian revolution, Soviet communism, international Marxism, and the need to respond critically and in a denunciatory fashion to the various mechanisms of repression and the frustration of personal and collective aspirations. In this regard, we can accept the critical viewpoints of Coles (2001):

Realism, in literature, is a manner and method of picturing life as it really is untouched by idealism or romanticism. As a manner of writing, realism relies on the use of specific details to interpret life faithfully and objectively. In contrast to romance, this concerned with the bizarre and psychological in its approach to character, presenting the individual rather than the type. Often, fate plays a major role in the action. Realism became prominent in the English novel with such writers as Daniel Defoe, Samuel Richardson, Henry Fielding, Tobias Smollett, Laurence Sterne, Jane Austen, Charlotte Bronte, Anthony Trollope and William Makepeace Thackeray (Dictionary of Literary Terms, p. 163).

The term 'Realism' is widely accepted according to need and time. Realism in literature and the visual art used to describe a variety of approach in which accurate depiction of reality is the aim. Each of these uses involves a contrast between human thought or imagination and an external reality independent of mind. The notion that reality has a cognitive or normative authority on the mind is generally present (Chapter 2: Social Realism, pp. 57).

Literature emerges out of life and records dreams and ideas, hopes and aspirations, failures and disappointments, motives and passions, and 
experiences and observations. Over the years, literature has reflected the prevailing social issues in many eminent works of literature under the shadow of realism. In Realism, social reality is an aspect of the picture but cannot be isolated as though it were an entity by itself. It cannot be taken out of the context of the general cultural pattern of a period. Even there have been honest attempts to recreate incidents from the great literatures of the past ages. They convey truth, the truth of emotion, which is the ultimate of realism. This aspect of realism is lacking in the works of some of the writers. Realism should be truthful and honest picture of society. It should be a true attempt to focus on reality with the concern to make it a superior world.

Realism in art and literature is an endeavor to portray life as it is. It shows life with reality, omitting nothing that is ugly or painful and idealizing nothing. To the realists, the writer's most important function is to describe as truthfully as possible what is observed through the senses. Realism began as a recognizable movement in art in the $18^{\text {th }}$ century. By the mid $19^{\text {th }}$ century, it was a principal art form. In the past, realism had been an upheaval against classicism and romanticism - artistic movements characterized by works that idealize life. Classicism shows life as being more rational and orderly than it really is; while Romanticism shows life as being more emotionally exciting and satisfying that it normally is. While it is an attempt through realism to represent life as it is. This 'life as it is' is what realism is. True realism depicts man and society as complete entities instead of showing one aspect or other. It is not just an echo but the real sound of an individual or society or joint voice of their being (Chapter III: Theory on Social Realism, pp. 2-5).

Social Realism developed as a reaction against idealism and the exaggerated ego encouraged by Romanticism. The consequences of the industrial revolution became an apparatus; urban centers grew, slums proliferated on a new scale contrasting with the display of wealth of the upper classes with a new sense of social consciousness and the social realists pledged to fight the beautiful art, any style which appeared to the eye or emotions. They focused on the ugly realities of contemporary life and sympathized with working class people, particularly the poor. They recorded what they saw, as it is existed in a dispassionate manner.

'Social' is an omnibus word covering all aspects of human activity that display an awareness of others. Simply speaking "Social Realism" is an extraordinary reach of understanding of social life. Still better, it is an intellectual power of probing into the nature and function of society, its various institutions and traditions, and their functioning. It is an intellectual penetration of social process.

Social Realism involves individual, social and cultural changes in all spheres of human life with their intricacies, and nuances: facts relating to family, the class, the marriage, the school, the politics, economy, morality, 
religion, and educational standards. It relates more to social readjustments and social maladjustments such as unemployment, youth unrest, industrial indiscipline, crime, war, and their causes and consequences. Social Realism is a keen depiction of social condition. Social insight is a heightened consciousness or comprehensive understanding of social and cultural milieu - a sense of social fact. Socially conscious refers to an awareness inspired by a social ideology. It implies extreme social involvement and commitment to social decorum. Social Realism includes social consciousness, social sense and experience and social insight. It is an all embracing term, indicating sound and systematic grasp of the socio-political web. Social Realism unravels the layer within layers of the social fabric through fictional medium. By choosing an appropriate story, characters, language and fictional technique, the novelist aims to present the multifarious aspects of society and its complex functioning. Social Realism is not just realism represented in novels. It is, on the other hand, the novelist's way of dealing with realism or sometimes dealing with social facts and events of society for his novel's sake. In the novelists' hands it remains a technique by which truth is represented in an artistic way (Chapter III: Theory on Social Realism, pp.79).

\section{Social Realism in Sherman Alexie's Literary Works}

If we scrutinize the literary works of Sherman Alexie, we can realize that social realism has been impacted in most of his writings, especially, poems, short stories, and novels. Alexie wants to show a faithful image of social reality of postmodern age through creating characters, plotconstruction, and themes. Alexie wants to highlight his subtle attitude towards social issues of his home country. What he wants to share with the people of the postmodern era is, equally true for any country of any age. Consequently, this submission is prepared to introduce social realism of Alexie's age so that we can get a clear-cut concept of psychological conflicts of both man and woman.

Alexie never writes about anything sacred, and he wants to present how Indians live in the postmodern world. He has a penchant for writing about bad things and unveiling them in the finest and the darkest environment. This is, probably, the most noticeable issue in the thriller full of hatred, rage and violence as impacted on Indian Killer, where he wants to represent his keen attitudes to social reality of his age. Although Alexie's work is based on everyday's real happenings of the Native American society, it does not mean that imagination is completely left out. It is visible, especially in his poetry. He offers the equation regarding it: poetry = anger ' $x$ ' imagination. He uses imagination in his works of fiction. For example, in his first novel, Reservation Blues a guitar can talk and the novel, Flight is 
about time travelling and its main character transforms into different historical characters (Grassian, 2005, p. 215). In Indian Killer and Reservation Blues, Alexie has highlighted important aspects of social realities of the Americans by shedding a new light upon his major characters so as to create consciousness among the communities.

We sense that the main pursuit of Alexie's writings is to explicate tendency of Indians in today's American society and to show his pride of becoming an Indian. Alexie's works contain his own social realistic judgments. In this regard, we can exemplify Indian Killer to highlight a harsh bait of the white society. His rejection of established stereotype and prejudice is also evident at first sight. He tries his level best to break down his contemporary stereotype, superstition, and prejudice. Actually, literature is one of the most effective ways for mirroring the index of human philosophy. We can also accept the definition of Mathew Arnold on literature: "Literature is the criticism of life." With this literary balance, Alexian literature is symbol of criticism of human life. Again some say that literature is the reflection of social picture and human character. Whatever definition of literature we can accept or not, the motif of any writer is to show his contemporary situations in the light of society, religion, politics, economics, and culture. But here in Alexian motto, we can understand that he has tried to introduce social picture from his poignant point of view. We cannot deny this fact.

Although Sherman Alexie's novels and short stories fall into the genre of fiction, it is no secret that he draws inspiration for his characters from the real people he gets mixed. In connection with this, Alexie has endured a lot of criticism for divulging the hidden truth of his society. People do not like his writings, because he is the real seer of human guilt. We can also see that he makes fun of his critics and they feel wounded by it. As musician Jim Boyd, Alexie’s collaborator and friend, explains:

On the reservation, we had our little secrets. Sherman has gone against that and sometimes the truth hurts. A lot of things he writes about just weren't out there before. But a lot of the things he talked about needed to be said (Campbell).

The quotation made above, we can behold that the society where Alexie resides condemns his writings because of the unsocial affairs of the white Americans. But he never surrenders to social injustice rather he continues writing.

Although Alexian oeuvres contain a variety of characters different from each other, some of his characters are repeated. Thomas Builds-theFire, a misfit storyteller of the Spokane tribe; Victor, an angry alcoholic guy and Junior, "the happy-go-lucky failure" appear both in the novel, Reservation Blues (1995) and in the short story collection, The Lone Ranger 
and Tonto Fist Fight in Heaven (1993). Alexie calls these three characters "the unholy trinity of me." Undoubtedly, these characters bear the testimony of his social reality because Alexie wants to unmask the alcoholic addiction and cruel traits of human character.

The protagonist of Indian Killer is a Native American, who was adopted out by a white couple. According to Alexie, Indians call Indian children adopted out by non-Indian families “lost birds.” One of Alexie's cousins was adopted out, which inspired him to create such character. Here the novelist has shed a new light of his autobiographical issues through his protagonist. In this regard, Alexian Indian Killer can be compared with David Lawrence's Sons and Lovers. Both novelists have focused on their own familial conflicts, forbidden attraction, psychological trauma of their respective age, because both Alexie and Lawrence have tasted the bitterness experiences in the same ways. In addition, we know that human life is made of sniffles, cries, weeps, sorrows and struggles as well. Alexie has experienced bitterly, what we see in his literary works.

As regards such themes Alexie depicts, it can be expressed that the majority of his writings have some in common, which include: despair, poverty, alcoholism, drug addiction, racial rowdy and alienation in today's society and the search of one's cultural identity, tensions between the white and Indian communities with the elements of racism and also sexual oppressions, especially inter-racial between Indian and non-Indian people. Alexie always tries to highlight the rift situations between the two communities in America. But Alexian ethical philosophy wants to compromise their clash through his writings. From the ethical point of view, we cannot but support Alexian writings. As a self-conscious reformer-cumcritics of his age, Alexie wants to speak the truth and to expose illogical aspects of the people of his age before all.

Now, in this research-work, I would like to introduce some major social problems of the Native Americans of Alexie's age with a view to creating sensibility as well as conscience in the mind of the postmodern people as follows:

\section{Poverty}

Sherman Alexie has bitter experiences regarding poverty at the very beginning of his life. As it is seen in most of his writings, despite pessimistic predictions, Alexie not only survived but also became a child prodigy, learning to read by the age of two. He was mocked by other children due to his intellectual superiority and the appearance of his enlarged skull, a result of his past medical condition. His family life offered little comfort or shelter. His father was an absentee alcoholic and his mother worked long hours as a trading-post clerk and quilt-maker in order to support the family of eight. 
The social rejection Alexie experienced drove him to become an avid reader and dedicated student. Similarly, if we bother our knowledge on a German Philosopher, Hegel, we can learn that Hegelian philosophy is based on pessimism. Hegel also tasted pessimistic experience from his childhood. After his father's demise, his mother had an illicit relationship with many suitors despite a famous authoress in Germany, and her suitors wound come and enjoy in her house in the presence of Hegel. But Hegel could not tolerate his mother's unsocial activities, and he tried to protest against his mother, but his mother drove him out from her house. At the time of his departure, Hegel said to his mother that one day she would see, this Hegel would become famous all over the world, and people would know Hegel by one name. Now we know Hegel by one name. Here we see in the life of Alexie, the white would despise Alexie and his family because they were the Native Indians, but Alexie, with his literary power, has enabled to capture their mind like Hegel. In this way, we can realize the pessimistic images of both Alexian literary and Hegelian philosophical writings.

However, throughout his literary works, Alexie explores the issues of despair, poverty, alcoholism, and racial conflict, which pervade everyday matters of the American Indians. His early collection of poetry and short fiction, The Business of Fancydancing, focuses on the social reality of the banal existence experienced on the reservation. Alexie evokes a type of spelled reality in which historical and fictional characters; like Crazy Horse and Buffalo Bill are embedded in the postmodern situations. He also creates Native-American characters, which frequently appear drinking, playing basketball, and sometimes committing small crimes. Irony, which influences Alexie's work, is used to juxtaposing conventional viewpoints about Native Americans with the contemporary faithful image of American Indian life. His characters show a sense of hopelessness in the struggle for physical and emotional existence and in the fight to cure a lost social identity. The Lone Ranger and Tonto Fistfight in Heaven captures a sense of a search for social redefinition by highlighting pain, desolation, and bitterness (Velie, 1991, p.375). Alexie also reminisces social reality by focusing on real and artificial social icons of the by-gone such as Jimi Hendrix, Elvis Presley, the Lone Ranger, and Tonto among reflections of 7-Eleven stores, television, basketball, and commodity food items. The structural style of The Lone Ranger and Tonto Fistfight in Heaven is considered fragmented and is constructed of introspective epiphanies by letting characters come to terms with the past and present interpretations of Native American culture. Alexie's first novel, Reservation Blues, shows the ups and downs of a Native American rock band with lofty expectations. One of Alexie's frequent characters, Thomas Builds-the-Fire, is given a guitar, which once belonged to the legendary blues musician Robert Johnson. Johnson donates the guitar 
to escape from a commitment what he has made with a devil. Consequently, the guitar is believed to be mystical. Alexie enlarges his characterizations of the Native American reservation inhabitants from his other writings, reiterating the adversity faced by American Indians. Alexie checks with the genre of mystery in his controversial novel, Indian Killer. Here, we see that John Smith, an American Indian adopted by white parents, is doubted, with other urban Native American characters of some murders in which the victims are scalped.

In The Summer of Black Widows, Alexie wants to represent a dark poetic humour, the hardship experienced on the reservation life, the Native American loss of identity, and the desecration of environment by getting interconnected with an abject acceptance of the modern American culture. Thus Alexie focuses on postmodern social reality of his age. Then, Alexie enters the world of film-making with his debut screenplay, Smoke Signals, an adaptation of his short fiction from The Lone Ranger and Tonto Fistfight in Heaven. The film is the first motion picture to feature both in front of the camera and behind the scenes-an all-Native-American cast. In his filmy creation, Alexie wants to show human character, social picture, and cultural identity of his own reservation. His literary works, through the diverse experiences and internal examination of his characters, and situation, aim to look at the social reality of the Native American in the light of the $21^{\text {st }}$ century postmodern era.

In the autobiographical novel, The Absolutely True Diary of a PartTime Indian, Alexie explores the struggle to survive between the grinding plates of the India and white worlds through the portrayal of his protagonist, Arnold Spirit. Alexie's portrayal of the reservation life is realistic, fantastical, funny, and tragic. In the novel, we see firsthand how devastating and awful poverty is not only for an individual, but for an entire community. We also find how poverty squashes expectation and dream on the reservation; how alcoholism is everywhere, which leads to premature death of the Native Americans. In this way, Alexi hopes to show a true picture of social reality of his contemporary age.

Based on the daily life of an American Indian teenager, Arnold Spirit, Alexie focuses on the realistic image of the current reservation life in America. Through analyzing the bleak surviving reality of the native Indians; the bitterness of the struggle of the protagonist, Arnold to achieve social success as well as native Indians' fear, hope, and expectation about future. The bleak surviving reality of reservation life highlights the uneven development of the native Indians in American society (Chun, 2014, p.83).

Arnold loses his grandmother and his sister. "I'm fourteen years old and I've been to forty-two funerals" (Alexie, 2007, p.199), Arnold says: "That's really the biggest difference between Indians and white people" 
(Alexie, 2007, p.199). In the community of Wellpinit, the reservation, everyone is related, everyone lives a miserable life, and everyone is at risk for untimely death. Poverty permeates the whole reservation: "Poverty = empty refrigerator + empty stomach. And sure, sometimes, my family misses a meal, and sleep is the only thing we have for dinner" (Alexie, 2007, p.8). Poverty not only afflicts physical harm but also mental and psychological trauma on the Native Indians:

It sucks to be poor, and it sucks to feel that you somehow deserve to be poor. You start believing that you're poor because you're stupid and ugly because you're India. And because you're Indian you start believing you're destined to be poor. It's an ugly circle and there's nothing you can do about it. Poverty doesn't give you strength or teach you lessons about perseverance. No, poverty only teaches you how to be poor (Alexie, 2007, p.13).

Alexie is a writer full of social responsibility. He thinks poverty, violence, and sex, though they are sensitive topics, they are inevitable parts of life and powerful shapers of his younger generation. With his direct depiction, he wants to draw the teen reader into the social realities of his life. As he responds to some complaints about the depiction of violence and sex in his article "Why the Best Kids Books Are Written in Blood" (2011), Alexie remarks that he visits many classrooms and receives many letters and messages from students who like to read his books, noting that these students have critical traumatic experiences similar to his own:

I have yet to receive a letter from a child somehow debilitated by the domestic violence, drug abuse, racism, poverty, sexuality, and murder contained in my book. To the contrary, kids as young as ten have sent me autobiographical letters written in crayon, complete with drawings inspired by my book that are just as dark, terrifying, and redemptive as anything I've ever read (Alexi, 2011, p.105).

From this quotation, we can realize that Alexie himself tastes the bitterness experience since his childhood when he begins to develop mentally and physically. These traumatic experiences, including: domestic violence, drug abuse, racism, poverty, sexuality, and murder make him conscious of the Native Americans regarding social realities, which are mostly impacted on his literary career.

In his famous novel, The Absolutely True Diary of a Part-Time Indian, Alexie faithfully exposes the social reality of Indian reservation. By throwing a light on Arnold's character as an indomitable, energetic, and promising Indian boy in adversity, we can express that the expectation harbors in American Indians. It is the aim that supports the American Indians to pursue a better life in the future. In this sense, Alexi's novel is a remarkable one, which is the symbol of social realism for all ages. 


\section{Suicidal Act}

Suicidal act is a very common affair among the Native Americans. Since 1980 suicide rates among young Native Americans (aged 15-24 years) increased 200\%-300\%. Suicide rates among Native Americans are threefold greater than the national average in USA. According to US statistics, young Indian male are more likely to commit suicide than female. Plain reservations are among the poor and suicide rate among the young Native Americans are tenfold greater than the US national average (Nieves, 2007).

According to critics and scholars, for what reasons do many young Native Americans decide to quit their lives voluntarily and prematurely? They also express their view that poverty, alcoholism, hopelessness, loss of identity, racial clash, psychological trauma, antagonistic criticism, and unemployment may be the plausible reasons for suicidal act. Alexie, with his literary poignant point of view, wants to foster the issues of suicidal act in his well-known novel, Reservation Blues and Indian Killer. In both discourses, suicide occurs mainly for an identity crisis. Consequently, characters suffer from it:

He was not afraid of falling. John stepped off the last skyscraper in Seattle. John fell. Falling in the dark, John Smith thought, was different from falling in the sunlight. It took more time to fall forty floors in the dark...John's fall was slow and precise...He had time to count the floors of the office tower across the street, ten, fifteen, thirty, forty. Time enough to look up and find the one bright window in a tower of dark glass across the street...Because he finally and completely understood the voices in his head... John was calm. He was falling (Alexie, 1996, pp. 411-12 ).

The quotation made above implies us that John committed a hideous and dreadful act for which he had to lose his life forever. He faced a premature death due to the crisis of identity and racial conflict. Through portraying John's character, Alexie also wants to show a true image of social reality like suicidal crime of the young Native Americans of the $21^{\text {st }}$ century.

\section{Alcoholism}

The portrayal of alcoholism, which has been rampant through the generations cannot be denied and presents a paradox with which the native writers must grapple. The pathetic city drunks and the pitiful alcoholic parents of the warm water sisters, Junior, Thomas, and Victor ring like wake up calls to the social problems faced by the Indian people. The representation of alcoholism in the text, Reservation Blues, highlights a stereotypical social image of the drunken Indian. It is not a kind of mirroring, portraying colonial impact, that non-native people want to accept and is a sore subject for the Indians, because it is very familiar for most of us. It is a dilemma for not 
only Alexie, but the Native writers in general: to minutely represent to our communities without exploiting them. The buffer in Reservation Blues is to sugarcoat the picture with side-tracks and comic scenes to tone down the real social issues. Despite the verisimilitude of Alexian portrayal of alcoholism and its impact upon the lives of the Native Americans, Alexie does not aim to put the social problems of economic instability, poverty, or cultural oppression into perspective (Coyhis, pp. 157-66). Instead, alcoholism and drinking are sensationalized: Lester is "the most accomplished drunk on the Spokane Reservation” (Schmidt, 2011), a notoriety that wins him "tribal hero" status. Victor, incapable of coping with rejection, turns to the bottle for solace like a tragic failed artist.

Sherman Alexie deals with the problem of alcohol in his work, as it is something inherent to the American Indians. Maybe, the reason is that alcoholism was a big problem in his family. For example, in his short story, “The Only Traffic on the Reservation Doesn't Flash Red Anymore” of the novel The Lone Ranger and Tonto Fistfight in Heaven, he tells the story of a young boy who is considered a reservation basketball star, but his promising future is destroyed by alcohol. In another short story, "What You Pawn I Will Redeem” of Ten Little Indians, Alexie gives a number of metaphorical names to alcohol, “a bottle of fortified courage” (Alexie, 2005, p.171) or "bottles of imagination" (Alexie, 2005, p.174) are good examples of it. In this way, Alexie wants to show harmful aspects of alcoholism through portraying a number of characters. At the same time, the poet-cum-novelist tries to make the Native Americans conscious of its effects. The stereotyped image of a "drunken Indian” (French, p.155) is commonly known throughout the United States dealing with Indian themes, but only few people ponder over it and try to find the causes and circumstances of Native Americans' malpractices. Alcoholism and issues connected with it have long represented the problem and it continues into the present.

\section{Racial Conflict}

Native Americans, as well as the members of other minorities do not avoid racism. It can begin by a subtle or not-so-subtle reference to skin colour and end by grievous bodily harm or another crime motivated by race. Sherman Alexie frequently writes about racism-related experiences by Native Americans. And, what is important, he writes about racism which he experienced from the very beginning of his life. In The Absolutely True Diary of a Part-Time Indian the main character, Junior, who represents the embodiment of a young Alexie, starts to attend all-white high school.

Then, the white kids began to attend to the school. They surrounded Alexie. Those kids were not just white. They were translucent. Alexie could see the blue veins running through their skin like rivers. Although the mascot 
of school football team is an Indian, Junior becomes the victim of racialrelated insults from the very beginning.

"Hey, Chief,” Roger said. "You want to hear a joke?”

"Sure," I said.

"Did you know that Indians are living proof that niggers fuck buffalo?”

I felt like Roger had kicked me in the face. That was the most racist thing I'd ever heard in my life (Alexie, 2012, p. 64).

However, Alexie does not write about racial tensions only from the perspective of an Indian victim of racism. Indian Killer is about a young Native American, who was named John by his white adoptive parents. Later in the novel, John begins to hate all the white men.

But John could not convince himself that the richest man in the world deserve to die. It was too easy. If he killed the richest white man in the world, then the second-richest white man would take his place. ... John could kill a thousand rich white men and not change a thing (Alexie, 1996, p. 28).

It is obvious from the above quotation that John does not hate only white people, he hates all white society. He is angry at them for what they have done to the world. He blames white men for his own bad situation, as well as for the miserable life of the other Indians.

"Fucking Indian!” ... "What the fuck are you staring at?"

John was staring at the white boys. They were pale and beautiful.

John pointed at them

"What the fuck you are pointing at" (Alexie, 1996, p. 96)?

John knew these white boys. Not these two in particular, but white boys in general. He had been in high school with boys like these. He hates them for who they are. John thinks that white people have better lives because of their skin colour and he resents their arrogant and haughty behaviour.

As regards to the real situation of Native Indians, whites and racism is a case which happened in Albuquerque, New Mexico in 2011. Three supporters of the "white power" assaulted and tortured a young Native American boy, who was mentally disabled as a result of fetal Alcohol syndrome. While he was sleeping, his torturers shaved a swastika into his hear and on the back of his neck they drew words "white power". After it, they covered his mouth by a towel and burned the sign of swastika on his arms. It was for the first time. However, Alexie sheds a new light of a grim picture of racial conflict between the Native Americans and the whites through portraying the character of John (Schmidt, 2011).

Social realism from Bangladesh perspectives, we can mention that many Bengali writers have focused on racial conflicts, poverty, drug 
addiction, unemployment problem, suicidal act and so on like Alexian literature. Alexian philosophy is equally true in a third world country like Bangladesh. So Alexie's poems, short stories and novels bear the testimony of universal appeal for all times of all ages. Many younger generations, poorer sections of communities and down trodden people are mostly victim of drug addiction, poverty, unemployment problem, suicidal act, and so forth here in Bangladesh.

Moreover, Alexie's literary works can be compared to Indian Subcontinent Dalit Literature, where the authors have focused the living conditions of the Dalit community in their writings. Subaltern and inferior beings are deprived of basic human needs; they suffer from malnutrition, various kinds of diseases, gender discrimination, racial conflicts, poverty, drug addiction, and so on.

Dalit writings mean- pain, sorrow, resistance, protest, classism, oppressed, suppressed, untouchable found in the literature of different countries. African-American writing or "Black writing" is created by the writers of African descent in United States. The pioneers of this writing are Phillis Wheatney and Olaudah Equiano, who began their work in late $18^{\text {th }}$ century. It has reached early high points with slave narratives of the $19^{\text {th }}$ century. African American Literature created advancing wave-front in the United States of America during the twentieth century as a voice of protest against racial discrimination. Similarly, Dalit literature also documents the socio-cultural and political factors of the exploited mass in India (Mandavkar, 2015, p.62).

Dalit Literature, which is about the oppressed according to the Indian caste system. People, who are called Dalits have a history of being lived in subjugation under the high-classes of Indian society. So, they have been a marginalized, downtrodden and subaltern group from centuries. But, because of the efforts of many social reformers like -Mahatma Jyotiba Phule, Dr. Ambedkar and Mahatma Gandhi, this community is also rising and progressing day-by-day. Still there are many problems related to their existence in the present scenario (Mandavkar, 2015, p. 63). However, the social picture of his age, what Alexie has mirrored in his literary works, we can see the same social image in Dalit literature as well. Thus we can determine a literary affinity between Dalit Literature and Alexian literary works.

\section{The Significance of the Study}

This research-work signifies a faithful image of the social reality of the postmodern Native Americans through Alexian writings. It represents the inner philosophical outlooks of Alexi towards the facets of social realism of his age. It aims to look at a binary opposition between the oppressed and the 
oppressor of the American communities. It also highlights awareness about familial conflicts, psychological traumas, drug addiction, racism, and poverty among not only the Native Americans, but also the people of the $21^{\text {st }}$ century globe.

\section{Research Methodology}

This study is based on my literary research conducted in the light of social realistic perspectives. The relevant literature is the only source of information for the preparation of the study. Another worth noting point in this context is that for the purpose of documentation, APA citation style has been followed strictly. This research-work has been done through the collection of primary and secondary materials available in the library, market and the internet. It has been done by analyzing and evaluating the pertinent sources at my disposal.

\section{Conclusion}

The study is based upon the perfect image of social reality of Native Americans through representing Sherman Alexie's literary works, especially Indian Killer, The Absolutely True Diary of a Part-Time Indian, Reservation Blues, The Lone Ranger and Tonto Fistfight in Heaven, and so on. Alexie wants to show daily affairs of his age by shedding a new light on extreme poverty, alcoholism, racism, feelings of loss of culture and identity.

This research-work based on "Social Realism" provides the facts which are drawn from Alexian literature in order to prove that his characters dealing with similar problems as real Native American do. However, the real social predicament of Native Americans seems to be worse than Alexie presents in his literature.

Truly speaking, the characters of Alexie's works face their social realities with a humorous and ironical style. That is the main difference between characters from works and real Indians from hopeless reservations who live from hand to mouth and often do not see any other way out from the harsh social reality than heavy drinking or, in the worst cases, a suicide. His biography proves that he grows up on the Indian reservation and then, he integrates into the white society of Seattle. Almost social realities are ascertained in this discussion what he experienced from his pragmatic point of view.

\section{References:}

\section{Primary Sources}

Alexie, Sherman. (1995). Reservation Blues. New York: The Atlantic Monthly Press 
. (1996). Indian Killer. ISBN 0-446-67370-6. New York: Warner

Books

. (2005). Ten Little Indians. London: Vintage, p. 243, ISBN 9780099464563

. (2012). The Absolutely True Diary of a Part-Time Indian. ISBN: 978-184-270-844-6, London: Anderssen Press

. (1992). The Business of Fancydancing: Short Stories and Poems. Brooklyn, New York: Hanging Loose Press

.(1993). The Lone Ranger and Tonto Fistfight in Heaven. New York: Harper Perennial

.(1994). "A Drug Called Tradition,” in The Lone Ranger and Tonto Fistfight in Heaven. New York: Harper Collins, pp.12-23

.(1994)."Because My Father Always Said He Was the Only Indian Who Saw Jimi Hendrix Play 'The Star Spangled Banner' at Woodstock," The Lone Ranger and Tonto Fistfight in Heaven. New York: Harper Collins, pp. 24-36

Hanging Loose

(1996). The Summer of Black Widows. Brooklyn, New York:

. (1998). Smoke Signals. New York: Hyperion

. (2007). Flight. New York: Black Cat

\section{Secondary Sources}

Campbell, D. (2003). Voice of the new tribes, The Guardian

Visit: http://www.guardian.co.uk/books/2003/jan/04/artsfeatures.fiction, retrieved 23 April 2013

Chun, Yang. (January 2014). “A Realistic Portrayal of Reservation Life: A Postcolonial Reading of The Absolutely True Diary of a Part-Time Indian,” in Sino-US English Teaching, ISSN 1539-8072, Vol. 11, No. 1, pp. 83-88

Coles Editorial Board. (2001). Dictionary of Literary Terms. New Delhi: Rama Brothers Educational Publishers, p.163.

Coyhis, D., White, W. L. Alcohol problems in native America: Changing paradigm and clinical practices, Alcoholism Treatment Quarterly, pp. 157166

French, L. A. Psychoactive agents and Native American spirituality: Past and Present, Contemporary Justice Review, p. 155

Grassian, D. (2005). Understanding Sherman Alexie, p. 215, ISBN 1-57003571-7, Columbia: University of South Carolina Press Highway, T. Spokane Words: An Interview with Sherman Alexie Visit: http://www.lang.osaka-u.ac.jp/ krkvls/salexie.html, retrieved 23 April 2013 
Mandavkar, Dr. Pavan. (April 2015). "Indian Dalit Literature Quest for Identity to Social Equality,” in Humanities \& Social Sciences Reviews Vol.: 3 (2), pp.60-69

Nieves, E. (2007).Indian Reservation Reeling in Wave of Youth Suicides and Attempts, The New York Times

Visit: http://www.nytimes.com/2007/06/09/us/09suicide.html?

Quirk, Sarah A. (2003). Dictionary of Literary Biography. $7^{\text {th }}$ Edition, 278, pp. 3-10

Reservation Blues, Amazon.com

Visit: $\quad$ http://www.amazon.com/Reservation-Blues-ShermanAlexie/dp/0802141900, retrieved 23 April 2013

Schmidt, D. J. (2011). “Branded and scarred”, Navajo Times

Visit: $\quad$ http://navajotimes.com/news/2011/0811/082511swastika.php, retrieved 23 April 2013

Slethuag, Gordon E. (2003). "Hurricanes and Fires: Chaotics in Sherman Alexie's Smoke Signals and The Lone Ranger and Tonto Fistfight in Heaven." Literature Film Quarterly 3

Velie, A. R. (1991). American Indian Literature: An Anthology. Oklahoma: University of Oklahoma Press, ISBN 0-8061-2345-1, p. 375

Website

Chapter 2: Social Realism- Shodhganga

shodhganga.inflibnet.ac.in/bitstream/10603/709/6/06_chapter\%202.pdf

Chapter III: Theory on Social Realism- Shodhganga

shodhganga.inflibnet.ac.in/bitstream/10603/8425/.../08_chapter\%203.pdf 